\title{
The role of dendritic cells in CNS autoimmunity
}

\author{
Alla L. Zozulya, \\ Department of Immunology, University of Geneva, Rue Gabrielle-Perret-Gentil 4, 1211, Genève \\ 14, Switzerland \\ Benjamin D. Clarkson, \\ Department of Pathology and Laboratory Medicine, University of Wisconsin-Madison, 1300 \\ University Avenue, Madison, WI 53706, USA \\ Sonja Ortler, \\ Department of Neurology, Clinical Research Group for MS and Neuroimmunology, University of \\ Wuerzburg, Josef-Schneider-Straße 11, 97080 Wuerzburg, Germany \\ Zsuzsanna Fabry, and \\ Department of Pathology and Laboratory Medicine, University of Wisconsin-Madison, 1300 \\ University Avenue, Madison, WI 53706, USA

\section{Heinz Wiendl} \\ Department of Neurology, Clinical Research Group for MS and Neuroimmunology, University of \\ Wuerzburg, Josef-Schneider-Straße 11, 97080 Wuerzburg, Germany \\ Heinz Wiendl: heinz.wiendl@klinik.uni-wuerzburg.de
}

\begin{abstract}
Multiple sclerosis (MS) is a chronic immune-mediated, central nervous system (CNS) demyelinating disease. Clinical and histopathological features suggest an inflammatory etiology involving resident CNS innate cells as well as invading adaptive immune cells. Encephalitogenic myelin-reactive $\mathrm{T}$ cells have been implicated in the initiation of an inflammatory cascade, eventually resulting in demyelination and axonal damage (the histological hallmarks of MS). Dendritic cells (DC) have recently emerged as key modulators of this immunopathological cascade, as supported by studies in humans and experimental disease models. In one such model, experimental autoimmune encephalomyelitis (EAE), CNS microvessel-associated DC have been shown to be essential for local antigen recognition by myelin-reactive T cells. Moreover, the functional state and compartmental distribution of DC derived from CNS and associated lymphatics seem to be limiting factors in both the induction and effector phases of EAE. Moreover, DC modulate and balance the recruitment of encephalitogenic and regulatory $\mathrm{T}$ cells into CNS tissue. This capacity is critically influenced by DC surface expression of co-stimulatory or co-inhibitory molecules. The fact that DC accumulate in the CNS before T cells and can direct T-cell responses suggests that they are key determinants of CNS autoimmune outcomes. Here we provide a comprehensive review of recent advances in our understanding of CNS-derived DC and their relevance to neuroinflammation.
\end{abstract}

\section{Keywords}

Dendritic cells; T-cell immune responses; Multiple sclerosis; Experimental autoimmune encephalomyelitis; CNS; Co-inhibitory molecules; B7-H1; PD-L1

Correspondence to: Heinz Wiendl, heinz.wiendleklinik.uni-wuerzburg. de.

Disclosure of potential conflict of interests The authors declare that they have no conflict of interests related to this study. 


\section{Introduction}

Dendritic cells are a heterogeneous (both ontogenetically and phenotypically) class of professional antigen-presenting cells (APC) with a potent capacity to initiate immune responses by interaction with T cells [1]. Importantly, DC are unique since they are the only professional APC that can prime naïve T cells and cross-present endocytosed antigenic peptides on both MHC class I or class II molecules. DC are also unique since they can be derived from both myeloid and lymphoid precursors and develop into functionally distinct subsets.

Myeloid (mDC) of myeloid origin and plasmacytoid (pDC) of lymphoid origin are two distinct subsets of DC in humans and mice (Table 1) [2]. While $\mathrm{mDC}$ and $\mathrm{pDC}$ have distinct cell-surface and cytokine profiles, both are capable of promoting adaptive responses after innate activation [3]. Different DC subsets differentially trigger adaptive immune responses depending on environmental factors (Table 1).

Following development, DC migrate to various tissues; capture, process, and present antigens; migrate to lymph nodes for interaction with T cells; and thereby modulate subsequent immune responses in accordance with their cell-surface complement of coreceptors [4]. Generally, DC are functionally distinguished as mature or immature, though only mature DC have the ability to activate T-cell effector function (Table 1) [4]. Though immature DC efficiently capture antigens for processing and presentation to naïve $\mathrm{T}$ cells, they are poor promoters of T-cell activation and may even downregulate immune responses. In contrast, inflammatory or infectious environments, characterized by NF- $\mathrm{KB}$ activation via IL-1/IL-18 or pattern recognition receptors, promote DC maturation, migration to secondary lymphoid organs, and induction of specific immune responses [5]. Maturation stabilizes MHC class I/II surface molecules and enhances expression of co-stimulatory molecules of the B7 family, which bind and activate T cells by their CD28 co-receptor [6,7]. Mature DC can prime T-cell responses but can also receive help and become 'licensed' to prime cytotoxic T lymphocyte (CTL) responses. As summarized in Table 1, immunogenic mature DC can direct T-cell polarities towards Th1 differentiation with high IL-12 production, or Th2-cell [8], and/or CTL priming.

Under low inflammatory or non-infectious conditions, DC downregulate immune responses. These 'regulatory' DC have a phenotype different from that of immature DC- they express a distinct combination of co-stimulatory and co-inhibitory surface molecules that promote peripheral tolerance and regulatory $\mathrm{T}$-cell $\left(\mathrm{T}_{\mathrm{reg}}\right)$ development [9]. Both immature and mature DC can suppress T-cell responses, with immature DC doing so without the phenotypic changes typically associated with maturation [10], and mature DC being rendered tolerogenic by signals from surrounding tissues [11]. Generally, DC maturation should not be viewed as a crucial switch between tolerance induction and immunity as discussed by C. Reis e Sousa [12]. Ultimately, understanding which phenotypic and ontogenic differences of DC subsets is crucial to developing effective DC-directed therapies for CNS autoimmunity.

\section{Distribution of DC in the brain}

Unambiguous identification of DC is difficult in the CNS due to their low frequency. Tissue in and around the CNS is comprised of several distinct compartments including the meninges, cerebrospinal fluid (CSF), CNS parenchyma, blood-brain barrier (BBB; bounded by endothelial cells and perivascular tissue), the blood-CSF barrier space (BCSF), and the brain-CSF barrier (bounded by ependymal cells and periventricular tissue). Each of these 
compartments has specific barriers to DC migration. The immune privilege of the CNS, involving both innate and adaptive immune responses, is limited to CNS parenchyma [13]. The perivascular or Virchow-Robin space that surrounds the tightly closed endothelial wall (BBB) in the CNS provides a fertile environment for T-cell activation. Recent evidence suggests that immune cell entry into the CNS parenchyma under inflammatory conditions involves vascular transmigration into the perivascular space followed by progression over the glia limitans into the parenchyma [14].

Though DC are rarely found in healthy CNS parenchyma, they can be detected histochemically in vascular-rich compartments such as the meninges and choroid plexus (CP) under normal conditions [15-17]. Additionally, both $\mathrm{mDC}$ and $\mathrm{pDC}$ have been found in the CSF of healthy patients [18], while other studies have confirmed substantial perivascular accumulation of DC in the brain and spinal cord in response to local inflammation induced by autoimmunity, infection, or trauma $[16,19]$. One recent study has also demonstrated active recruitment of pDC into the CNS and their accumulation in white matter lesions and leptomeninges of patients with MS [20]. This strongly supports the view that DC participate in neuroinflammatory autoimmune responses.

Although a contribution of CNS-derived DC to the integrity and pathology of the healthy and inflamed CNS has been suggested [21-23], the origin of these CNS-derived DC is still a matter of debate. In vitro experiments have shown that DC in the CNS could arise from resident microglia in the presence of the growth factor granulocyte-macrophage colonystimulating factor (GM-CSF) $[24,25]$. Other cytokines known to induce DC differentiation such as TNF- $\alpha$, IL-1, and IL-6 have also been detected in the CNS [26]. The growth factor FMS-like tyrosine kinase 3 ligand (Flt-3L) induces expansion of DC numbers via proliferation and/or differentiation [27]. Furthermore, it has been shown that Flt-3L specifically recruits DC to brain parenchyma [28].

It has also been suggested that DC are recruited to the CNS from the periphery. During the acute phase of an immune response, bone marrow stromal cells are activated to promote release of DC precursors and other monocytes into circulation. Bone marrow-derived DC can migrate across an artificial BBB in vitro. Interestingly, upon migration, they show an activated phenotype and are able to induce antigen-specific T-cell proliferation [29]. In addition to migration of differentiated DC, monocytes were observed to differentiate into DC upon migration across endothelium in vitro [30,31]. The possibility of such an event in vivo has to be further studied but remains a potential source of DC localized in the CNS. Recent work delineates microglia and microenvironment of CNS as main contributors to immune barrier of CNS, effecting DC function through their differentiation into microglialike cells with inhibitory function [32].

Chemokines (MCP-1, RANTES/MIP-1 $\alpha$, CCL19/CCL21) and their respective chemokine receptors CCR2, CCR5, and CCR7 have been specifically implicated in DC migration [3336]. For example, peripheral lymphoid tissue highly expresses CCL19 and CCL21, ligands for CCR7, which was identified on DC in MS lesions. This supports the hypothesis that DC recruited to inflammatory sites in the CNS retain their capacity to migrate to the periphery with CNS autoantigens and activate naïve T cells [37]. The discovery of myelin-containing DC in the lymph nodes of MS patients and the repeatable recovery of intracerebrally injected DC from CNS-related lymph nodes also support this hypothesis [38,39].

\section{The role of DC in EAE}

The mechanism by which CNS-derived DC induce suppressive or autoreactive T cells remains a subject of debate. Indeed, the complex interaction between DC and T cells during neuroinflammation can only be studied to a limited extent ex vivo. Thus, appropriate in vivo 
models of neuro-inflammation are necessary to further deepen our understanding of these interactions, chief of which has been experimental autoimmune encephalomyelitis (EAE). Several studies have contributed to the notion that APCs in the brain play a key role in determining the outcome of CNS inflammation [19,40,41]. Although numerous studies unambiguously emphasize the potential relevance of DC for CNS immune surveillance or autoimmune reactions, the true contribution of DC in the initiation and perpetuation of neuroantigen-specific $\mathrm{T}$-cell responses remains elusive.

Severity of EAE as well as the number of MS plaques seems to correlate with the presence and functional status of DC $[18,40,42]$. In accordance with these studies, it was recently shown that DC presence in the CNS might serve as a limiting factor for neuroinflammation during CNS autoimmunity. Intracerebral injections of bone marrow-derived DC loaded with MOG peptide resulted in exacerbation of EAE clinical scores associated with the accumulation of $\mathrm{CD}^{+}$and $\mathrm{CD} 8^{+} \mathrm{T}$ cells in the $\mathrm{CNS}$ and a disrupted balance between encephalitogenic and regulatory T cells. Specifically, experimental accumulation of DC in the CNS resulted in an enrichment of FoxP3-negative neuroantigen-specific T cells in the CNS at the expense of FoxP3 ${ }^{+} T_{\text {reg }}$ cells [43]. Similarly, it has been shown that $\mathrm{mDC}$ preferentially accumulated in the perivascular inflammatory foci of the spinal cord and cerebellum, clustering there with T cells at the peak of EAE. These mDC uniquely potentiated Th17 and not Th1 differentiation, which was corroborated by their enhanced expression of TGF- $\beta$, IL-6, and IL-23 [21].

In contrast to $\mathrm{mDC}, \mathrm{pDC}$ within the CNS were relatively inefficient in stimulating $\mathrm{CD} 4^{+} \mathrm{T}$ cells to produce IL-17, were insignificant in T-cell activation and epitope spreading, and therefore have been suggested to play a tolerogenic role during EAE [21]. CNS-associated $\mathrm{pDC}$ appeared to negatively regulate pathogenic CNS-associated $\mathrm{CD}^{+}{ }^{+} \mathrm{T}$-cell responses, concurring with a regulatory role for pDC in inflammatory autoimmune diseases [44].

Regulatory $\mathrm{T}$ cells can be divided into at least three categories: natural $\mathrm{T}_{\mathrm{reg}}\left(\mathrm{nT}_{\mathrm{reg}}\right)$ produced in the thymus, and two forms of adaptive or inducible $\mathrm{T}_{\text {reg }}$ (iTreg), $\mathrm{Th} 3$ and $\operatorname{Tr} 1$, derived from conventional T cells in the periphery by TGF- $\beta$ and IL-10, respectively. Collectively, these cells have been shown to be key enforcers of peripheral immune tolerance [45,46]. For example, Hirata et al. demonstrated that the accumulation of FoxP3 ${ }^{+} \mathrm{T}_{\text {reg }}$ cells in the spinal cord of mice injected with MOG-pulsed DC expressing TRAIL (a member of the TNF superfamily) decreased EAE severity in treated mice [47]. The authors also presented data suggesting that $\mathrm{DC}$ could induce $\mathrm{T}_{\text {reg }}$ differentiation from activated $\mathrm{T}$ cells in the target organ (CNS) rather than during priming of naïve T cells in peripheral lymphoid tissue [47].

Given its anatomical complexity and immune-privileged status, CNS tissue can hardly be considered a typical effector tissue, and whether this form of DC-T cell interaction is unique to CNS tissue remains to be seen. Furthermore, several CNS compartments surrounding the blood-brain and blood-CSF barriers have been proposed to serve as functional lymphoid tissue, where these putative DC-T cell interactions may also be occurring.

\section{DC and other CNS resident cells express B7-H1, which shapes the CNS microenvironment during immune response}

As mentioned above, the appearance of DC in the brain indicates that they might be responsible for the initiation or amplification of CNS-directed adaptive immune responses. Studying the functional and phenotypical characteristics that define how DC respond to and modulate the local environmental milieu in order to effect various T-cell responses may help elucidate the immunomodulatory role of these cells in CNS inflammatory diseases. 
The DC-T cell synapse is comprised of an uncompromisingly complex collection of receptors and co-receptors, allowing $\mathrm{T}$ cells and $\mathrm{DC}$ to share a unique reciprocal relationship [48]. Along with the MHC peptide: TCR-CD3-CD4/8 complex, B7-1 (CD80) and B7-2 (CD86) molecules on DC both bind to either CD28 or CTLA-4 to induce effector and suppressor functions in T cells, respectively. In addition to the classical B7/CD28 pathway of co-stimulation, the inhibitory B7 homologues B7-H1 and B7-DC (PDL1 and PDL2, respectively) [49] expressed on mature DC in humans and mice [50] have been shown to play an important role inducing T-cell tolerance by binding PD-1 [51].

Due to its broad expression pattern in lymphoid and non-lymphoid organs, the B7-H1/PD-1 pathway has been suggested to play a crucial role for the maintenance of immune tolerance [52,53]. A series of studies have demonstrated that B7-H1/PD-1 and not B7-DC/PD-1 signaling is central to parenchymal immune responses during CNS inflammation [54-58]. Specifically, peripheral neuroantigen-specific IFN- $\gamma / \mathrm{IL}-17$ T-cell responses occurred earlier and were enhanced in $\mathrm{B} 7-\mathrm{H}^{-/-}$mice, but also ceased more rapidly exclusively in the periphery [59]. This demonstrates the role of B7-H1 in limiting parenchymal inflammation but also suggests a role for B7-H1 as a 'survival' factor for activated antigen-specific T cells in peripheral effector sites; again, this function may be restricted to CNS tissue where inducible expression of $\mathrm{B} 7-\mathrm{H} 1$ on parenchymal CNS cells has been proposed to limit detrimental immune reactions [59].

The relevance of B7-H1 expression on professional APC during primary immune responses in the CNS parenchyma has not yet been studied. Recently, we demonstrated an unexpected beneficial effect from B7-H1 $1^{-1-} \mathrm{DC}$, where intracerebral microinjections resulted in amelioration of subsequent EAE [60]. Furthermore, this treatment was accompanied by amplified neuroantigen-specific $\mathrm{CD} 8^{+} \mathrm{T}_{\text {reg }}$ recruitment into the CNS. Our study suggests that the lack of DC-derived B7-H1 allows for the development (or recruitment) of regulatory $\mathrm{CD}^{+} \mathrm{T}$ cells $\left(\mathrm{CD} 122^{+}\right)$in the CNS. The mechanism for this action is not understood; however, in Fig. 1, we postulate one putative action of B7-H1 in DC-T-cell interactions during immune response, which could account for this unexpected outcome. In this scenario, B7-H1 binds B7-1 to compete off CD-28/CTLA-4 binding. Not mutually exclusive, B7-H1 might also be required as a survival signal for brain-derived $\mathrm{CD} 8^{+}$regulatory $\mathrm{T}$ cells. Additionally, B7-H1 has recently been shown to possess stimulatory activity by acting through a novel receptor in PD- $1^{-/-}$mice [61]. Nevertheless, CNS-associated DC expression of B7-H1 is suggested to play a key role in maintenance of $\mathrm{CD} 8^{+} \mathrm{T}_{\text {reg }}$, which potently regulates CNS inflammation in EAE [62].

\section{The role of DC in MS}

To date, only a few studies have distinctly assessed the role of DC in MS patients, as separate from the function of microglia, pericytes, and infiltrating macrophage. Huang et al. reported elevated numbers of peripheral blood DC in MS patients [63]. DC were found increased in frequency and activation markers in blood and cerebrospinal fluid (CSF) of patients with MS. Both mDC and pDC could be found in the CSF of MS patients, suggesting their active participation in the immunopathogenesis [18,63]. A recent study demonstrated active recruitment and accumulation of $\mathrm{pDC}$ into CNS white matter lesions and leptomeninges of patients with MS [20]. In addition, others have reported altered DC phenotype and dysfunctional interaction of DC with T cells in MS patients [64,65]. However, it has to be noted critically that the exact mechanism of $\mathrm{pDC} / \mathrm{mDC}$ accumulation and their roles during CNS inflammation are not well understood.

The frequency and phenotype of circulating $\mathrm{mDC}$ and $\mathrm{pDC}$ in human serum suggests deficient DC maturation in primary progressive MS (PPMS) patients [66]. Treatment with 
high-dose intravenous methylprednisolone (IVMP) during MS relapse results in symptomatic amelioration that correlates well with both increased numbers of blood $\mathrm{T}_{\text {reg }}$ cells and reduced numbers of $\mathrm{mDC}$ and $\mathrm{pDC}$ during the short-term treatment. IFN- $\beta$, the most widely used treatment for PPMS, has also been shown to upregulate B7-H1 on DC, thus potentially increasing their suppressive properties and contributing to DC-mediated immune regulation relevant to MS [67]. Concordantly, other studies have claimed a role for IFN- $\beta$ in inducing $T_{\text {reg }}$ via DC-T cell interactions $[68,69]$. While our understanding of DC involvement in MS is still in its infancy, these data demonstrate that DC are key therapeutic targets.

\section{From bench to bedside: considerations for translating basic research into clinical therapies for MS}

Since DC are capable of potentiating both detrimental and suppressive T-cell functions, aberrancies in the functional status of specific DC subpopulations likely contribute to the dysfunctional immune regulation associated with CNS autoimmunity. Additionally, the extensive involvement of DC in the initiation and maintenance of neuroinflammation provides strong rationale for targeting DC for the treatment of MS. Experimental results in EAE suggest that disruption of DC differentiation, maturation, brain-barriers transmigration, antigen presentation, or T-cell polarization may be therapeutically effective. This, however, must be tempered by the risks and uncertainties inherent to DC-directed therapies. Thus, specific modulation of DC function in chronic autoimmune neuroinflammation is a potentially powerful if also extremely challenging therapeutic option.

A number of currently used therapeutic approaches in different diseases act by modulating DC functional status. A summary of known effects of DC-targeted drugs is presented in Table 2. Among drugs currently being studied are the steroids (dexamethasone, corticosterone, prednisone, and methylprednisolone), estrogen, and estrogen receptor modulators (tamoxifen and rolixfene); statins (simvastatin and atorvastatin); immunosuppressants (mycophenolate mofetil, FK506, cyclosporine A, vasoactive intestinal peptide, rapamycin, glatiramer acetate, $1 \alpha 25$, dihydroxy-vitamin $D_{3}$, TGF- $\beta$, IFN- $\beta$, and IL-10); the South Asian Plant extract andrographolide; the antihistamine cetirizine; and monoclonal antibodies to p-glycoprotein (MDR-1) and CD31. However, none of these examples is as of yet a specific DC-directed therapy, but rather exerts direct and indirect effects via the DC arm of the immune system.

The promise of genetically engineered DC or in vitro-manipulated DC has been demonstrated in a number of elegant studies in various models of transplantation or allograft acceptance, which also serve as models of inflammation (reviewed in [70]). DC targeting has also been shown to be effective for amplifying anti-tumor responses in some patients with metastatic melanoma [71]. Similarly, tolerized DC could be used to suppress anti-self responses in patients with autoimmune diseases. The use of a signal transduction inhibitor (CEP-701), primarily targeting DC, showed promising results in EAE, dampening the autoreactive polarizing condition driven by DC [72]. One recent study demonstrated a therapeutic benefit of targeting neuroantigen to tolerized DC in vivo [73]. Also, the use of transgenic mice lacking TGF- $\beta R$ signaling in DC resulted in augmented EAE-associated Tcell responses, suggesting a role of TGF- $\beta$ in controlling autoimmunity through DC [74]. However, the prospects of in vitro-manipulated DC as a potential therapeutic avenue in autoimmune disease remain largely uninvestigated [72]. The challenges of this approach include targeting DC to the appropriate lymphoid organs and effector sites and ensuring DC do not induce undesired T-cell responses. One possible consideration would be using CSF as a therapeutic route for transfer of therapeutically modified DC; however, the migration 
pattern for cells delivered in this fashion and the possibility of further immune complications (such as BBB compromise) remain largely unknown. While this approach is technically feasible, many unresolved questions yet exist for tissue-specific DC therapy. For example, there is an expected risk of general immunosuppression, which could lead to opportunistic infection or reactivation of latent infections that have been shown to be prevalent in the patient population such as Epstein-Barr virus [75]. Additionally, there is a risk of more general immune deviation, which poses the risk of exacerbating various hypersensitivity reactions, such as allergies or asthma. Thus far, there is no concrete strategy for specific manipulation of the pertinent CNS DC that leaves other immune cell populations relatively unaffected.

\section{Concluding remarks}

New data about the involvement and role of resident CNS cells in shaping the innate immune response and relationship with $\mathrm{T}$ cells provide new insights into the intrinsic capacity of CNS to maintain immune homeostasis and to face autoimmunity (reviewed in [22]). DC have increasingly been implicated as key modulators of CNS immunity. Thus, elucidating the migratory routes by which DC traffic to and from the brain and how DC modulate CNS immune responses will be crucial for understanding the progression of CNS autoimmunity and developing appropriate therapeutic strategies.

Unfortunately, a number of challenges are encountered in translating the information garnered from studying EAE into human therapy for CNS autoimmunity. To this end, a better understanding of the mechanisms responsible for DC development, maturation, and migration into CNS tissue is unambiguously required. For example, it is still unclear whether DC can mature from microglia in vivo into fully functioning DC and what proportion of CNS-related DC are derived peripherally from monocyte populations. Moreover, given the anatomical complexity of compartmental barriers surrounding CNS tissue, the migration of DC to and from inflammatory sites in brain parenchyma is assuredly more complex than our current understanding. Despite these uncertainties, manipulation of DC migration and function should still be considered as a reasonable therapeutic target for future treatment of MS and other neuroinflammatory diseases.

\section{References}

1. Banchereau J, Steinman RM. Dendritic cells and the control of immunity. Nature. 1998; 392:245. [PubMed: 9521319]

2. Shortman K, Liu YJ. Mouse and human dendritic cell subtypes. Nat Rev Immunol. 2002; 2:151. [PubMed: 11913066]

3. Kadowaki N, Antonenko S, Lau JY, Liu YJ. Natural interferon alpha/beta-producing cells link innate and adaptive immunity. J Exp Med. 2000; 192:219. [PubMed: 10899908]

4. Steinman RM. The dendritic cell system and its role in immunogenicity. Annu Rev Immunol. 1991; 9:271. [PubMed: 1910679]

5. Matzinger P. Friendly and dangerous signals: is the tissue in control? Nat Immunol. 2007; 8:11. [PubMed: 17179963]

6. Inaba K, Witmer-Pack M, Inaba M, Hathcock KS, Sakuta H, Azuma M, Yagita H, Okumura K, Linsley PS, Ikehara S, Muramatsu S, Hodes RJ, Steinman RM. The tissue distribution of the B7-2 costimulator in mice: abundant expression on dendritic cells in situ and during maturation in vitro. $\mathrm{J}$ Exp Med. 1994; 180:1849. [PubMed: 7525841]

7. Schuler G, Steinman RM. Murine epidermal Langerhans cells mature into potent immunostimulatory dendritic cells in vitro. J Exp Med. 1985; 161:526. [PubMed: 3871837]

8. Langenkamp A, Messi M, Lanzavecchia A, Sallusto F. Kinetics of dendritic cell activation: impact on priming of TH1, TH2 and nonpolarized T cells. Nat Immunol. 2000; 1:311. [PubMed: 11017102] 
9. Menges M, Rossner S, Voigtlander C, Schindler H, Kukutsch NA, Bogdan C, Erb K, Schuler G, Lutz MB. Repetitive injections of dendritic cells matured with tumor necrosis factor alpha induce antigen-specific protection of mice from autoimmunity. J Exp Med. 2002; 195:15. [PubMed: 11781361]

10. Villadangos JA, Heath WR. Life cycle, migration and antigen presenting functions of spleen and lymph node dendritic cells: limitations of the Langerhans cells paradigm. Semin Immunol. 2005; 17:262. [PubMed: 15946854]

11. Kapsenberg ML. Dendritic-cell control of pathogen-driven T-cell polarization. Nat Rev Immunol. 2003; 3:984. [PubMed: 14647480]

12. Reis e Sousa C. Dendritic cells in a mature age. Nat Rev Immunol. 2006; 6:476. [PubMed: 16691244]

13. Galea I, Bechmann I, Perry VH. What is immune privilege (not)? Trends Immunol. 2007; 28:12. [PubMed: 17129764]

14. Owens T, Bechmann I, Engelhardt B. Perivascular spaces and the two steps to neuroinflammation. J Neuropathol Exp Neurol. 2008; 67:1113. [PubMed: 19018243]

15. Matyszak MK, Perry VH. The potential role of dendritic cells in immune-mediated inflammatory diseases in the central nervous system. Neuroscience. 1996; 74:599. [PubMed: 8865208]

16. McMenamin PG. Distribution and phenotype of dendritic cells and resident tissue macrophages in the dura mater, leptomeninges, and choroid plexus of the rat brain as demonstrated in wholemount preparations. J Comp Neurol. 1999; 405:553. [PubMed: 10098945]

17. Serot JM, Bene MC, Foliguet B, Faure GC. Monocyte-derived IL-10-secreting dendritic cells in choroid plexus epithelium. J Neuroimmunol. 2000; 105:115. [PubMed: 10742552]

18. Pashenkov M, Huang YM, Kostulas V, Haglund M, Soderstrom M, Link H. Two subsets of dendritic cells are present in human cerebrospinal fluid. Brain. 2001; 124:480. [PubMed: 11222448]

19. Bailey SL, Schreiner B, McMahon EJ, Miller SD. CNS myeloid DCs presenting endogenous myelin peptides 'preferentially' polarize $\mathrm{CD} 4+\mathrm{T}(\mathrm{H})-17$ cells in relapsing EAE. Nat Immunol. 2007; 8:172. [PubMed: 17206145]

20. Lande R, Gafa V, Serafini B, Giacomini E, Visconti A, Remoli ME, Severa M, Parmentier M, Ristori G, Salvetti M, Aloisi F, Coccia EM. Plasmacytoid dendritic cells in multiple sclerosis: intracerebral recruitment and impaired maturation in response to interferon-beta. J Neuropathol Exp Neurol. 2008; 67:388. [PubMed: 18431257]

21. Bailey SL, Carpentier PA, McMahon EJ, Begolka WS, Miller SD. Innate and adaptive immune responses of the central nervous system. Crit Rev Immunol. 2006; 26:149. [PubMed: 16700651]

22. Fabry Z, Schreiber HA, Harris MG, Sandor M. Sensing the microenvironment of the central nervous system: immune cells in the central nervous system and their pharmacological manipulation. Curr Opin Pharmacol. 2008; 8:496. [PubMed: 18691672]

23. Suter T, Biollaz G, Gatto D, Bernasconi L, Herren T, Reith W, Fontana A. The brain as an immune privileged site: dendritic cells of the central nervous system inhibit T cell activation. Eur J Immunol. 2003; 33:2998. [PubMed: 14579268]

24. Fischer HG, Reichmann G. Brain dendritic cells and macrophages/microglia in central nervous system inflammation. J Immunol. 2001; 166:2717. [PubMed: 11160337]

25. Santambrogio L, Belyanskaya SL, Fischer FR, Cipriani B, Brosnan CF, Ricciardi-Castagnoli P, Stern LJ, Strominger JL, Riese R. Developmental plasticity of CNS microglia. Proc Natl Acad Sci USA. 2001; 98:6295. [PubMed: 11371643]

26. Willenborg DO, Staykova MA. Cytokines in the pathogenesis and therapy of autoimmune encephalomyelitis and multiple sclerosis. Adv Exp Med Biol. 2003; 520:96. [PubMed: 12613575]

27. Maraskovsky E, Brasel K, Teepe M, Roux ER, Lyman SD, Shortman K, McKenna HJ. Dramatic increase in the numbers of functionally mature dendritic cells in Flt3 ligand-treated mice: multiple dendritic cell subpopulations identified. J Exp Med. 1996; 184:1953. [PubMed: 8920882]

28. Curtin JF, King GD, Barcia C, Liu C, Hubert FX, Guillonneau C, Josien R, Anegon I, Lowenstein PR, Castro MG. Fms-like tyrosine kinase 3 ligand recruits plasmacytoid dendritic cells to the brain. J Immunol. 2006; 176:3566. [PubMed: 16517725] 
29. Zozulya AL, Reinke E, Baiu DC, Karman J, Sandor M, Fabry Z. Dendritic cell transmigration through brain microvessel endothelium is regulated by MIP-1alpha chemokine and matrix metalloproteinases. J Immunol. 2007; 178:520. [PubMed: 17182592]

30. Alt C, Laschinger M, Engelhardt B. Functional expression of the lymphoid chemokines CCL19 (ELC) and CCL 21 (SLC) at the blood-brain barrier suggests their involvement in G-proteindependent lymphocyte recruitment into the central nervous system during experimental autoimmune encephalomyelitis. Eur J Immunol. 2002; 32:2133. [PubMed: 12209625]

31. Randolph GJ, Beaulieu S, Lebecque S, Steinman RM, Muller WA. Differentiation of monocytes into dendritic cells in a model of transendothelial trafficking. Science. 1998; 282:480. [PubMed: 9774276]

32. Bai B, Song W, Ji Y, Liu X, Tian L, Wang C, Chen D, Zhang X, Zhang M. Microglia and microglia-like cell differentiated from DC inhibit CD4 T cell proliferation. PLoS ONE. 2009; 4:e7869. [PubMed: 19924241]

33. Izikson L, Klein RS, Charo IF, Weiner HL, Luster AD. Resistance to experimental autoimmune encephalomyelitis in mice lacking the CC chemokine receptor (CCR)2. J Exp Med. 2000; 192:1075. [PubMed: 11015448]

34. Pashenkov M, Teleshova N, Kouwenhoven M, Kostulas V, Huang YM, Soderstrom M, Link H. Elevated expression of CCR5 by myeloid (CD11c+) blood dendritic cells in multiple sclerosis and acute optic neuritis. Clin Exp Immunol. 2002; 127:519. [PubMed: 11966770]

35. Trebst C, Sorensen TL, Kivisakk P, Cathcart MK, Hesselgesser J, Horuk R, Sellebjerg F, Lassmann H, Ransohoff RM. CCR1+/CCR5+ mononuclear phagocytes accumulate in the central nervous system of patients with multiple sclerosis. Am J Pathol. 2001; 159:1701. [PubMed: 11696431]

36. Sellebjerg F, Madsen HO, Jensen CV, Jensen J, Garred P. CCR5 delta32, matrix metalloproteinase-9 and disease activity in multiple sclerosis. J Neuroimmunol. 2000; 102:98. [PubMed: 10626673]

37. Kivisakk P, Mahad DJ, Callahan MK, Sikora K, Trebst C, Tucky B, Wujek J, Ravid R, Staugaitis SM, Lassmann H, Ransohoff RM. Expression of CCR7 in multiple sclerosis: implications for CNS immunity. Ann Neurol. 2004; 55:627. [PubMed: 15122702]

38. de Vos AF, van Meurs M, Brok HP, Boven LA, Hintzen RQ, van der Valk P, Ravid R, Rensing S, Boon L, t Hart BA, Laman JD. Transfer of central nervous system autoantigens and presentation in secondary lymphoid organs. J Immunol. 2002; 169:5415. [PubMed: 12421916]

39. Karman J, Ling C, Sandor M, Fabry Z. Initiation of immune responses in brain is promoted by local dendritic cells. J Immunol. 2004; 173:2353. [PubMed: 15294948]

40. Greter M, Heppner FL, Lemos MP, Odermatt BM, Goebels N, Laufer T, Noelle RJ, Becher B. Dendritic cells permit immune invasion of the CNS in an animal model of multiple sclerosis. Nat Med. 2005; 11:328. [PubMed: 15735653]

41. McMahon EJ, Bailey SL, Castenada CV, Waldner H, Miller SD. Epitope spreading initiates in the CNS in two mouse models of multiple sclerosis. Nat Med. 2005; 11:335. [PubMed: 15735651]

42. Serafini B, Rosicarelli B, Magliozzi R, Stigliano E, Capello E, Mancardi GL, Aloisi F. Dendritic cells in multiple sclerosis lesions: maturation stage, myelin uptake, and interaction with proliferating T cells. J Neuropathol Exp Neurol. 2006; 65:124. [PubMed: 16462204]

43. Zozulya AL, Ortler S, Lee J, Weidenfeller C, Sandor M, Wiendl H, Fabry Z. Intracerebral dendritic cells critically modulate encephalitogenic versus regulatory immune responses in the CNS. J Neurosci. 2009; 29:140. [PubMed: 19129392]

44. Bailey-Bucktrout SL, Caulkins SC, Goings G, Fischer JA, Dzionek A, Miller SD. Cutting edge: central nervous system plasmacytoid dendritic cells regulate the severity of relapsing experimental autoimmune encephalomyelitis. J Immunol. 2008; 180:6457. [PubMed: 18453561]

45. Korn T, Reddy J, Gao W, Bettelli E, Awasthi A, Petersen TR, Backstrom BT, Sobel RA, Wucherpfennig KW, Strom TB, Oukka M, Kuchroo VK. Myelin-specific regulatory T cells accumulate in the CNS but fail to control autoimmune inflammation. Nat Med. 2007; 13:423. [PubMed: 17384649] 
46. O'Connor RA, Malpass KH, Anderton SM. The inflamed central nervous system drives the activation and rapid proliferation of Foxp3+ regulatory T cells. J Immunol. 2007; 179:958. [PubMed: 17617587]

47. Hirata S, Matsuyoshi H, Fukuma D, Kurisaki A, Uemura Y, Nishimura Y, Senju S. Involvement of regulatory $\mathrm{T}$ cells in the experimental autoimmune encephalomyelitis-preventive effect of dendritic cells expressing myelin oligodendrocyte glycoprotein plus TRAIL. J Immunol. 2007; 178:918. [PubMed: 17202353]

48. Hubert P, Jacobs N, Caberg JH, Boniver J, Delvenne P. The cross-talk between dendritic and regulatory T cells: good or evil. J Leukoc Biol. 2007; 82:781-794. [PubMed: 17652446]

49. Dong H, Zhu G, Tamada K, Chen L. B7-H1, a third member of the B7 family, co-stimulates T-cell proliferation and interleukin-10 secretion. Nat Med. 1999; 5:1365. [PubMed: 10581077]

50. Freeman GJ, Long AJ, Iwai Y, Bourque K, Chernova T, Nishimura H, Fitz LJ, Malenkovich N, Okazaki T, Byrne MC, Horton HF, Fouser L, Carter L, Ling V, Bowman MR, Carreno BM, Collins M, Wood CR, Honjo T. Engagement of the PD-1 immunoinhibitory receptor by a novel B7 family member leads to negative regulation of lymphocyte activation. J Exp Med. 2000; 192:1027. [PubMed: 11015443]

51. Sharpe AH, Freeman GJ. The B7-CD28 superfamily. Nat Rev Immunol. 2002; 2:116. [PubMed: 11910893]

52. Nishimura H, Honjo T. PD-1: an inhibitory immunoreceptor involved in peripheral tolerance. Trends Immunol. 2001; 22:265. [PubMed: 11323285]

53. Nishimura H, Minato N, Nakano T, Honjo T. Immunological studies on PD-1 deficient mice: implication of PD-1 as a negative regulator for B cell responses. Int Immunol. 1998; 10:1563. [PubMed: 9796923]

54. Carter LL, Leach MW, Azoitei ML, Cui J, Pelker JW, Jussif J, Benoit S, Ireland G, Luxenberg D, Askew GR, Milarski KL, Groves C, Brown T, Carito BA, Percival K, Carreno BM, Collins M, Marusic S. PD-1/PD-L1, but not PD-1/PD-L2, interactions regulate the severity of experimental autoimmune encephalomyelitis. J Neuroimmunol. 2007; 182:124. [PubMed: 17182110]

55. Cheng X, Zhao Z, Ventura E, Gran B, Shindler KS, Rostami A. The PD-1/PD-L pathway is upregulated during IL-12-induced suppression of EAE mediated by IFN-gamma. J Neuroimmunol. 2007; 185:75. [PubMed: 17320975]

56. Liang SC, Latchman YE, Buhlmann JE, Tomczak MF, Horwitz BH, Freeman GJ, Sharpe AH. Regulation of PD-1, PD-L1, and PD-L2 expression during normal and autoimmune responses. Eur J Immunol. 2003; 33:2706. [PubMed: 14515254]

57. Salama AD, Chitnis T, Imitola J, Ansari MJ, Akiba H, Tushima F, Azuma M, Yagita H, Sayegh MH, Khoury SJ. Critical role of the programmed death-1 (PD-1) pathway in regulation of experimental autoimmune encephalomyelitis. J Exp Med. 2003; 198:71. [PubMed: 12847138]

58. Zhu B, Guleria I, Khosroshahi A, Chitnis T, Imitola J, Azuma M, Yagita H, Sayegh MH, Khoury SJ. Differential role of programmed death-ligand 1 [corrected] and programmed death-ligand 2 [corrected] in regulating the susceptibility and chronic progression of experimental autoimmune encephalomyelitis. J Immunol. 2006; 176:3480. [PubMed: 16517716]

59. Ortler S, Leder C, Mittelbronn M, Zozulya AL, Knolle PA, Chen L, Kroner A, Wiendl H. B7-H1 restricts neuroantigen-specific $\mathrm{T}$ cell responses and confines inflammatory CNS damage: implications for the lesion pathogenesis of multiple sclerosis. Eur J Immunol. 2008; 38:1734. [PubMed: 18421793]

60. Zozulya AL, Ortler S, Fabry Z, Sandor M, Wiendl H. The level of B7 homologue 1 expression on brain DC is decisive for CD8 Treg cell recruitment into the CNS during EAE. Eur J Immunol. 2009; 39:1536. [PubMed: 19424967]

61. Wang S, Bajorath J, Flies DB, Dong H, Honjo T, Chen L. Molecular modeling and functional mapping of B7-H1 and B7-DC uncouple costimulatory function from PD-1 interaction. J Exp Med. 2003; 197:1083. [PubMed: 12719480]

62. Waisman A, Yogev N. B7-H1 and CD8+ Treg: the enigmatic role of B7-H1 in peripheral tolerance. Eur J Immunol. 2009; 39:1448. [PubMed: 19499529] 
63. Huang YM, Xiao BG, Ozenci V, Kouwenhoven M, Teleshova N, Fredrikson S, Link H. Multiple sclerosis is associated with high levels of circulating dendritic cells secreting pro-inflammatory cytokines. J Neuroimmunol. 1999; 99:82. [PubMed: 10496180]

64. Navarro J, Aristimuno C, Sanchez-Ramon S, Vigil D, Martinez-Gines ML, Fernandez-Cruz E, de Andres C. Circulating dendritic cells subsets and regulatory T-cells at multiple sclerosis relapse: differential short-term changes on corticosteroids therapy. J Neuroimmunol. 2006; 176:153. [PubMed: 16698092]

65. Stasiolek M, Bayas A, Kruse N, Wieczarkowiecz A, Toyka KV, Gold R, Selmaj K. Impaired maturation and altered regulatory function of plasmacytoid dendritic cells in multiple sclerosis. Brain. 2006; 129:1293. [PubMed: 16513684]

66. Lopez C, Comabella M, Al-zayat H, Tintore M, Montalban X. Altered maturation of circulating dendritic cells in primary progressive MS patients. J Neuroimmunol. 2006; 175:183. [PubMed: 16698091]

67. Schreiner B, Mitsdoerffer M, Kieseier BC, Chen L, Hartung HP, Weller M, Wiendl H. Interferonbeta enhances monocyte and dendritic cell expression of B7-H1 (PD-L1), a strong inhibitor of autologous T-cell activation: relevance for the immune modulatory effect in multiple sclerosis. $\mathrm{J}$ Neuroimmunol. 2004; 155:172. [PubMed: 15342209]

68. Berghella AM, Totaro R, Pellegrini P, Contasta I, Russo T, Carolei A, Adorno D. Immunological study of IFNbeta-1a-treated and untreated multiple sclerosis patients: clarifying IFNbeta mechanisms and establishing specific dendritic cell immunotherapy. Neuroimmunomodulation. 2005; 12:29. [PubMed: 15756051]

69. Pellegrini P, Totaro R, Contasta I, Berghella AM, Carolei A, Adorno D. CD30 antigen and multiple sclerosis: CD30, an important costimulatory molecule and marker of a regulatory subpopulation of dendritic cells, is involved in the maintenance of the physiological balance between TH1/TH2 immune responses and tolerance. The role of IFNbeta-1a in the treatment of multiple sclerosis. Neuroimmunomodulation. 2005; 12:220. [PubMed: 15990453]

70. Morelli AE, Thomson AW. Tolerogenic dendritic cells and the quest for transplant tolerance. Nat Rev Immunol. 2007; 7:610. [PubMed: 17627284]

71. Palucka K, Ueno H, Fay J, Banchereau J. Harnessing dendritic cells to generate cancer vaccines. Ann N Y Acad Sci. 2009; 1174:88. [PubMed: 19769741]

72. Skarica M, Wang T, McCadden E, Kardian D, Calabresi PA, Small D, Whartenby KA. Signal transduction inhibition of APCs diminishes th17 and Th1 responses in experimental autoimmune encephalomyelitis. J Immunol. 2009; 182:4192. [PubMed: 19299717]

73. Blanchfield JL, Mannie MD. A GMCSF-neuroantigen fusion protein is a potent tolerogen in experimental autoimmune encephalomyelitis (EAE) that is associated with efficient targeting of neuroantigen to APC. J Leukoc Biol. 2010; 87:509-521. [PubMed: 20007248]

74. Laouar Y, Town T, Jeng D, Tran E, Wan Y, Kuchroo VK, Flavell RA. TGF-beta signaling in dendritic cells is a prerequisite for the control of autoimmune encephalomyelitis. Proc Natl Acad Sci USA. 2008; 105:10865. [PubMed: 18669656]

75. Hasserjian RP, Chen S, Perkins SL, de Leval L, Kinney MC, Barry TS, Said J, Lim MS, Finn WG, Medeiros LJ, Harris NL, O’Malley DP. Immunomodulator agent-related lymphoproliferative disorders. Mod Pathol. 2009; 22:1532. [PubMed: 19767727]

76. Kajiwara T, Tomita Y, Okano S, Iwai T, Yasunami Y, Yoshikai Y, Nomoto K, Yasui H, Tominaga R. Effects of cyclosporin A on the activation of natural killer T cells induced by alphagalactosylceramide. Transplantation. 2007; 83:184. [PubMed: 17264815]

77. Penna G, Amuchastegui S, Giarratana N, Daniel KC, Vulcano M, Sozzani S, Adorini L. 1, 25Dihydroxyvitamin D3 selectively modulates tolerogenic properties in myeloid but not plasmacytoid dendritic cells. J Immunol. 2007; 178:145. [PubMed: 17182549]

78. Steinbrink K, Wolfl M, Jonuleit H, Knop J, Enk AH. Induction of tolerance by IL-10-treated dendritic cells. J Immunol. 1997; 159:4772. [PubMed: 9366401]

79. Kuwana M, Kaburaki J, Wright TM, Kawakami Y, Ikeda Y. Induction of antigen-specific human CD4(+) T cell anergy by peripheral blood DC2 precursors. Eur J Immunol. 2001; 31:2547. [PubMed: 11536152] 
80. Fallarino F, Asselin-Paturel C, Vacca C, Bianchi R, Gizzi S, Fioretti MC, Trinchieri G, Grohmann U, Puccetti P. Murine plasmacytoid dendritic cells initiate the immunosuppressive pathway of tryptophan catabolism in response to CD200 receptor engagement. J Immunol. 2004; 173:3748. [PubMed: 15356121]

81. Gilliet M, Liu YJ. Human plasmacytoid-derived dendritic cells and the induction of T-regulatory cells. Hum Immunol. 2002; 63:1149. [PubMed: 12480258]

82. Gilliet M, Liu YJ. Generation of human CD8 T regulatory cells by CD40 ligand-activated plasmacytoid dendritic cells. J Exp Med. 2002; 195:695. [PubMed: 11901196]

83. Moseman EA, Liang X, Dawson AJ, Panoskaltsis-Mortari A, Krieg AM, Liu YJ, Blazar BR, Chen W. Human plasmacytoid dendritic cells activated by $\mathrm{CpG}$ oligodeoxynucleotides induce the generation of CD4+CD25+ regulatory T cells. J Immunol. 2004; 173:4433. [PubMed: 15383574]

84. Kadowaki N. Dendritic cells—a conductor of T cell differentiation. Allergol Int. 2007; 56:193. [PubMed: 17646736]

85. Ito T, Yang M, Wang YH, Lande R, Gregorio J, Perng OA, Qin XF, Liu YJ, Gilliet M. Plasmacytoid dendritic cells prime IL-10-producing T regulatory cells by inducible costimulator ligand. J Exp Med. 2007; 204:105. [PubMed: 17200410]

86. Kawamura K, Kadowaki N, Kitawaki T, Uchiyama T. Virus-stimulated plasmacytoid dendritic cells induce CD4+ cytotoxic regulatory T cells. Blood. 2006; 107:1031. [PubMed: 16219801]

87. Miller SD, McMahon EJ, Schreiner B, Bailey SL. Antigen presentation in the CNS by myeloid dendritic cells drives progression of relapsing experimental autoimmune encephalomyelitis. Ann N Y Acad Sci. 2007; 1103:179. [PubMed: 17376826]

88. Schnurr M, Toy T, Shin A, Wagner M, Cebon J, Maraskovsky E. Extracellular nucleotide signaling by $\mathrm{P} 2$ receptors inhibits IL-12 and enhances IL-23 expression in human dendritic cells: a novel role for the cAMP pathway. Blood. 2005; 105:1582. [PubMed: 15486065] 


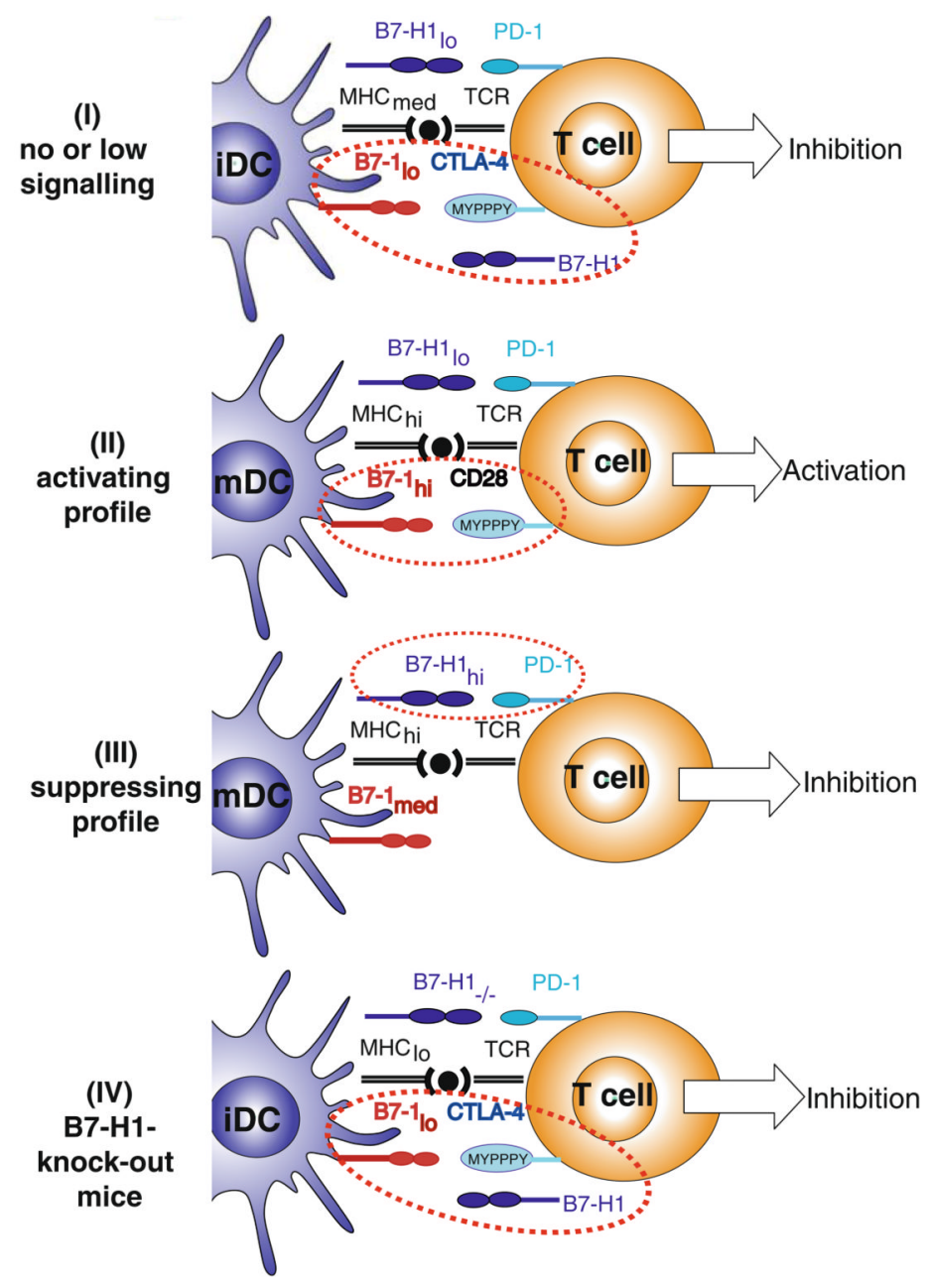

Fig. 1.

The role of B7-H1 expression on DC during immune response. The following mechanism of action of B7-H1 is postulated in accordance with B7-1 affinities for B7-H1, CD28, and CTLA-4 $(\mathrm{kd}=1.4,4.0$, and $0.4 \mu \mathrm{M}$, respectively). At homeostatic levels, B7-H1 competes with CTLA-4 for B7-1 binding, thus providing in concert with MHC molecules a nonactivating signal that promotes naïve T-cell survival, while simultaneously suppressing $\mathrm{T}$ cell responses by outcompeting with $\mathrm{B} 7-1 / \mathrm{CD} 28$, thereby effectively reducing the dynamic range of T-cell responses in healthy tissue. (I) Under low B7-1 expression, T-cell signaling through CTLA-4 leads to incomplete T-cell activation resulting in suppressor phenotype. (II) Under high B7-1 expression, T-cell signaling through CD28 leads to T-cell activation resulting in effector phenotype. (III) Upon B7-H1 upregulation, this molecule is capable of avidly binding PD-1, thereby exhibiting its inhibitory effect. (IV) However, in the absence of B7-H1 expression (B7-H1 $1^{-l-}$ mice) without B7-H1 to compete with CTLA-4, low B7-1 expression also develops T-cell signaling through CTLA-4, resulting in suppressor phenotype. $i D C$ immature dendritic cells, tolDC tolerogenic dendritic cells, $m D C$ mature dendritic cells, $h i$ high expression, lo low expression, med medium expression, CTLA-4 cytotoxic T lymphocyte-associated antigen 4, TCR T-cell receptor 


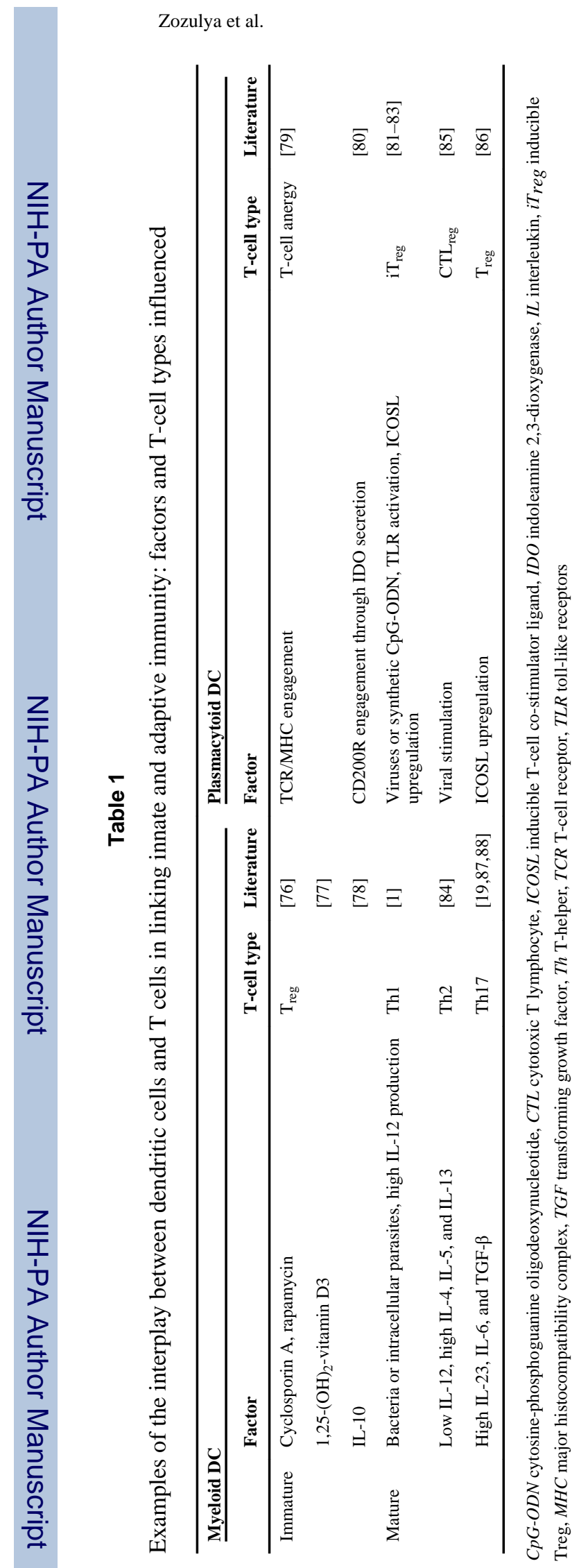

Page 14 
Table 2

Therapeutic manipulations targeting or affecting DCs

\begin{tabular}{|c|c|c|c|}
\hline $\begin{array}{l}\text { Level of DC } \\
\text { interference }\end{array}$ & Drug & & Mechanism of action \\
\hline \multirow[t]{2}{*}{ Differentiation } & Glucocorticoids IFN-beta & Estrogen Receptor & $\begin{array}{l}\text { Inhibition of monocyte and/or bone marrow-derived } \\
\text { precursors differentiation into DC }\end{array}$ \\
\hline & Vitamin $\mathrm{D}_{3}$ & Modulators & \\
\hline \multirow[t]{4}{*}{ Maturation } & Glucocorticoids Statins & Vitamin $\mathrm{D}_{3} \mathrm{IL}-10$ & $\begin{array}{l}\text { Downregulation of co-stimulatory molecules: CD } 40 \text {, } \\
\text { CD83, CD86, and MHCII }\end{array}$ \\
\hline & Mycophenolate mofetil & TGF- $\beta$ & \\
\hline & Modulators & Estrogen & \\
\hline & Cyclosporin A & Receptor & \\
\hline \multirow[t]{6}{*}{$\begin{array}{l}\text { Antigen uptake and } \\
\text { presentation }\end{array}$} & Dexamethasone Statins & Cetirizine IL-10 & $\begin{array}{l}\text { Impaired macropinocytosis and mannose receptor- } \\
\text { mediated endocytosis in bone marrow-derived DC }\end{array}$ \\
\hline & Mycophenolate mofetil & TGF- $\beta$ & \\
\hline & Rapamycin & Andrographolide & Reduced capacity to activate alloreactive T cells \\
\hline & Cyclosporin A & Tacrolimus (FK506) & Consequent to agents binding MHC molecules \\
\hline & Vitamin $\mathrm{D}_{3}$ & Glatiramer acetate & Decrease in nuclear translocation of NF- $\kappa \mathrm{B}$ \\
\hline & & & Upregulation of IDO or PGE2 release \\
\hline \multirow[t]{3}{*}{ Polarization bias } & Glucocorticoids Cyclosporin A & Statins Interferon- $\beta$ & $\begin{array}{l}\text { Inhibited production of Th1-favoring cytokines, IL-6, } \\
\text { IL-12, and TNF } \alpha\end{array}$ \\
\hline & $\begin{array}{l}\text { Mycophenolate mofetil Tacrolimus } \\
\text { (FK506) }\end{array}$ & VIP & $\begin{array}{l}\text { Increased production of Th2 or Treg-mediating } \\
\text { cytokines, IL-10, IL-5, IL-13, and TGF- } \beta\end{array}$ \\
\hline & Vitamin $\mathrm{D}_{3}$ & & \\
\hline \multirow[t]{2}{*}{ Migration } & Dexamethasone Cyclosporin A & Anti-MDR1 mAb & Increased expression of MCP-1 \\
\hline & Vitamin $\mathrm{D}_{3}$ & Anti-CD31 mAb & Blockade of CCR7 or other chemokine receptors \\
\hline \multirow[t]{2}{*}{ Death } & Prednisolone Rapamycin & Vitamin $\mathrm{D}_{3} \mathrm{IL}-10$ & Induction of apoptosis and inhibition of cell survival \\
\hline & Estradiol & & \\
\hline
\end{tabular}

$I D O$ indoleamine 2,3-dioxygenase, $I L$ interleukin, $T G F$ transforming growth factor, $M C P$-1 monocyte chemoattractant protein-1, MDR-1 multidrug-resistant protein, $V I P$ vasoactive intestinal peptide, $P G E 2$ prostaglandin $\mathrm{E} 2$ 